\title{
Dechlorination and chlorine rearrangement of 1,2,5,5,6,9,10- heptachlorodecane mediated by the whole pumpkin seedlings
}

\author{
Yanlin Li a, b, Xingwang Hou ${ }^{\text {b, c }}$, Miao Yu ${ }^{\text {b, c }}$, Qunfang Zhou ${ }^{\text {b, c }}$, Jiyan Liu ${ }^{\text {b, c, * }}$, \\ Jerald L. Schnoor ${ }^{\mathrm{d}}$, Guibin Jiang ${ }^{\mathrm{b}, \mathrm{c}}$ \\ a School of Earth and Space Sciences, University of Science and Technology of China, Hefei, 230026, China \\ ${ }^{\mathrm{b}}$ State Key Laboratory of Environmental Chemistry and Ecotoxicology, Research Center for Eco-Environmental Sciences, Chinese Academy of Sciences, P.O. \\ Box 2871, Beijing, 100085, China \\ ${ }^{\mathrm{c}}$ College of Resources and Environment, University of Chinese Academy of Sciences, Beijing, 100049, China \\ ${ }^{\mathrm{d}}$ Department of Civil and Environmental Engineering, University of Iowa, Iowa City, IA, USA
}

\section{A R T I C L E I N F O}

\section{Article history:}

Received 29 October 2016

Received in revised form

10 February 2017

Accepted 16 February 2017

Available online 24 February 2017

Handling Editor: Chen Da

\begin{abstract}
A B S T R A C T
Short chain chlorinated paraffins (SCCPs) are ubiquitously present as persistent organic pollutants in the environment. However, little information on the interaction of SCCPs with plants is currently available. In this work, young pumpkin plants (Cucurbita maxima $\times$ C. Moschata) were hydroponically exposed to the congener of chlorinated decane, 1,2,5,5,6,9,10-heptachlorodecane (1,2,5,5,6,9,10-HepCD), to investigate the uptake, translocation and transformation of chlorinated decanes in the intact plants. It was found that parent HepCD was taken up by the pumpkin roots, translocated from root to shoots, and phytovolatilized from pumpkin plants to air via the plant transpiration flux. Our data suggested that dechlorination of 1,2,5,5,6,9,10-HepCD to lower chlorinated decanes and rearrangement of chlorine atoms in the molecule were all mediated by the whole pumpkin seedlings. Chlorinated decanes were found in the shoots and roots of blank controls, indicating that chlorinated decanes in the air could be absorbed by leaves and translocated from shoots to roots. Lower chlorinated congeners $\left(\mathrm{C}_{10} \mathrm{H}_{17} \mathrm{Cl}_{5}\right)$ tended to detain in air compared to higher chlorinated congeners $\left(\mathrm{C}_{10} \mathrm{H}_{16} \mathrm{Cl}_{6}\right.$ and other $\left.\mathrm{C}_{10} \mathrm{H}_{15} \mathrm{Cl}_{7}\right)$. Potential transformation pathway and behavior of 1,2,5,5,6,9,10-HepCD in pumpkin were proposed based on these experiments.
\end{abstract}

(C) 2017 Elsevier Ltd. All rights reserved.

\section{Introduction}

Chlorinated paraffins (CPs), as a group of highly complex industrial chemicals, are produced by direct free radical chlorination of different n-alkane fractions from petroleum distillation (Zencak and Oehme, 2006). They have been widely used as additives, flame retardants, plasticizers, and cutting fluids (Bayen et al., 2006). According to the length of carbon chain, chlorinated paraffins are classified into short chain CPs (SCCPs, $\mathrm{C}_{10-13}$ ), medium chain CPs (MCCPs, $\mathrm{C}_{14-17}$ ) and long chain CPs (LCCPs, $\mathrm{C}_{18-30}$ ) with chlorine mass contents from 30 to $70 \%$ (Pellizzato et al., 2007). Among CPs, SCCPs have been under review for inclusion in Stockholm

\footnotetext{
* Corresponding author. State Key Laboratory of Environmental Chemistry and Ecotoxicology, Research Center for Eco-Environmental Sciences, Chinese Academy of Sciences, P.O. Box 2871, Beijing, 100085, China.

E-mail address: liujy@rcees.ac.cn (J. Liu).
}

Convention on Persistent Organic Pollutants (POPs) (UNEP, 2015) because of their long-distance atmospheric transport (Tomy et al., 2000), persistence (Iozza et al., 2008), bioaccumulation (Houde et al., 2008) and toxicities in the environment (Burýšková et al., 2006; Cooley et al., 2001; Geng et al., 2015; Madeley and Birtley, 1980). The toxicities of SCCPs are generally more prominent than those of MCCPs and LCCPs (Feo et al., 2009).

Currently, most of researches on the environmental occurrence and fate of SCCPs have been conducted in various environmental matrixes, such as air (Barber et al., 2005; Fridén et al., 2011; Li et al., 2012; Wang et al., 2012a,b), water (Bayen et al., 2006; Houde et al., 2008), soil (Gao et al., 2012; Wang et al., 2013), sediment (Huttig and Oehme, 2005; Štejnarová et al., 2005), sludge (Zeng et al., 2012, 2013), the aquatic food web (Ma et al., 2014), and the urban and remote area samples (Tomy et al., 1999). Spatial and temporal distributions of SCCPs in China and other countries have been reported (Chen et al., 2011; Iozza et al., 2008; Marvin et al., 2003). It has been found that SCCPs with high $\log K_{\text {ow }}$ values (3.82-11.3) 
(Hilger et al., 2011) can be bioaccumulated and biomagnified in marine and lake food webs (Houde et al., 2008; Ma et al., 2014). Some microbial species were identified to be capable of biotransforming CPs (Heath et al., 2006; Lu, 2013).

Plants play an important role in the metabolism and global cycling of all sorts of organic contaminants in the environment (Collins et al., 2006). There are a number of reports on the bioaccumulation and metabolism of organic pollutants in plants. For example, poplar plants and tobacco cells are not only able to take up but also to metabolize PCBs (Liu and Schnoor, 2008; Liu et al., 2009; Rezek et al., 2008; Zhai et al., 2010a, 2010b). In the study by Wang et al. (2011a,b, 2012a,b), three PBDEs (BDE-15, BDE-28 and BDE-47) and three PCBs (PCB-15, PCB-28 and PCB-47) were hydroponically exposed to maize, in which metabolism of PBDEs and PCBs were compared. The translocation and bioaccumulation of DDT by Cucurbita pepo species (pumpkin and zucchini) have been studied (Lunney et al., 2004). However, little information on fate and metabolism of SCCPs in plants is available. In our previous work, pumpkin plants were found to have high abilities to accumulate, hydroxylate and methoxylate halogenated organic compounds, such as BDE-28 (Yu et al., 2013) and BDE-47 (Sun et al., 2013). Thus, pumpkin seedlings were selected in this study to investigate the uptake, translocation and transformation of SCCPs in the intact plant after hydroponic exposure. Due to the restriction of commercially available standard compound, an individual parent chlorodecane, 1,2,5,5,6,9,10-HepCD, was selected. The parent HepCD probably has a different chlorination pattern compared to those in the technical mixtures (Tomy et al., 1998). And different properties were found for chloroalkanes with different chlorination patterns (Hilger et al., 2011). Though the selected chlorodecane could not represent all the SCCPs, we hope the behaviors of chlorodecanes interfacing with the plant could be preliminarily explored using the individual standard with the relatively simple hydroponic exposure system.

\section{Experimental section}

\subsection{Chemicals and reagents}

Commercial standards, including 1,2,5,6,9-pentachlorodecane (1,2,5,6,9-PCD), 1,2,5,6,9,10-hexachlorodecane $\quad(1,2,5,6,9,10-$ HexCD), 1,2,4,5,9,10-hexachlorodecane (1,2,4,5,9,10-HexCD), 1,2,4,5,6,9,10-heptachlorodecane (1,2,4,5,6,9,10-HepCD), 1,2,5,5,6,9,10-heptachlorodecane (1,2,5,5,6,9,10-HepCD), SCCPs mixtures (three $\mathrm{C}_{10-13}$ standard with chlorine contents of $51.5,55.5$ and $63.0 \%$, three $C_{10}$ standards with chlorine contents of 44.82 , 60.09 , and $65.02 \%$, and injection standard of $\varepsilon$-hexachlorocyclohexane ( $\varepsilon-\mathrm{HCH}, 10 \mathrm{mgL}^{-1}$ in cyclohexane, 99.9\%), were purchased from Ehrenstorfer $\mathrm{GmbH}$ (Augsburg, Germany). 1,1,1,3,9,10-hexachlorodecane $(1,1,1,3,9,10-\mathrm{HexCD})$ was purchased from Chiron, Norway. The surrogate standard, ${ }^{13} \mathrm{C}_{10}$-trans-chlordane (100 $\mathrm{mgL}^{-1}$ in $n$-nonane, 99.9\%), was obtained from Cambridge Isotope Laboratories (Andover, USA). The information on individual chlorinated decane congeners, including the congener codes, purities and concentrations, are listed in Table 1. The concentrations of decane standard solutions from Ehrenstorfer $\mathrm{GmbH}$ have been adjusted according to the purity of the compounds indicated by the instruction.

Florisil (60-100 mesh, Sigma-Aldrich, St. Louis, USA) was activated at $140{ }^{\circ} \mathrm{C}$ for $7 \mathrm{~h}$. Silica gel $(0.063-0.100 \mathrm{~mm}$, Merck, Darmstadt, Germany) was activated at $550^{\circ} \mathrm{C}$ for $12 \mathrm{~h}$. Acid silica gel were the mixtures of activated silica and concentrated $\mathrm{H}_{2} \mathrm{SO}_{4}$. Anhydrous sodium sulfate $\left(\mathrm{Na}_{2} \mathrm{SO}_{4}\right)$ was heated for $6 \mathrm{~h}$ at $660^{\circ} \mathrm{C}$ prior to use by the muffle furnace. Then, all of these were stored in a sealed desiccator. The solvents used for analysis, including hexane, dichloromethane, acetone, cyclohexane, purchased from J.T. Baker (Phillipsburg, NJ, USA), were all pesticide grade. All other chemicals and reagents used were of at least analytical grade. Ultrapure water $(18.3 \mathrm{M} \Omega \times \mathrm{cm})$ was obtained from a Milli-Q purification system (Millipore, Billerica, USA).

\subsection{Hydroponic exposure}

Seeds of pumpkin (Cucurbita maxima $\times$ C. moschata, TaiguYinong Seed CO., Ltd, Shanxi, China) were pre-germinated on the filter paper drenched with deionized water for $3-4$ days $\left(33^{\circ} \mathrm{C}\right.$, darkness). Then the seedlings were grown on sterilized perlite beds for about 7-10 days. Before exposure, seedlings were moved into the sterile deionized water without perlite for two days. Healthy pumpkin seedlings (shoots height of 5-6 cm) of similar growth and status were chosen for 1,2,5,5,6,9,10-HepCD exposure experiments. The growth and exposure conditions were $25^{\circ} \mathrm{C}$ with $16 \mathrm{~h}$ light/8 h dark. The photoperiod was maintained with a light intensity of $250 \mu \mathrm{mol} \mathrm{m}{ }^{-2} \mathrm{~s}^{-1}$.

As shown in Fig. 1, exposure group I (5 parallel reactors), unplanted control group ( 5 reactors), and blank control group ( 3 reactors) were set-up simultaneously in the exposure chamber. Reactors for exposure experiments were $50 \mathrm{~mL}$ brown glass conical flasks. The conical flasks and the deionized water used for exposure were all autoclaved $\left(120^{\circ} \mathrm{C}\right.$ for $\left.20 \mathrm{~min}\right)$ to eliminate the possible exotic microorganisms. Each reactor was filled with $40 \mathrm{~mL}$ of deionized water and $8000 \mathrm{ng}$ of 1,2,5,5,6,9,10-HepCD (dissolved in $800 \mu \mathrm{L}$ of acetone) to obtain an initial exposure concentration of $196 \mathrm{ng} / \mathrm{mL}$, and then planted with four pumpkin seedlings. The roots of plants were rinsed by autoclaved deionized water before transferring into the reactors. The whole reactors were wrapped with aluminum foil to provide darkness condition for the roots and to avoid any possible transformation of the 1,2,5,5,6,9,10-HepCD unrelated to plants. The aluminum foil also helped to fix the pumpkins to make sure that only roots emerged into the hydroponic solutions. All procedures were conducted in a laminar flow hood. Unplanted controls were added with 1,2,5,5,6,9,10-HepCD but without pumpkin seedlings. Glass rods stood in the reactors instead of the plants to simulate the loss of 1,2,5,5,6,9,10-HepCD mainly resulted from volatilization and possible chemical transformation. Blank controls were planted with pumpkin seedlings, added with $800 \mu \mathrm{L}$ of acetone but without parent compound to control the cross contamination.

To further study the transport of chlorodecanes through air, exposure group II (3 reactors) was set-up. Each reactor of exposure group II was placed into a $1.5 \mathrm{~L}$ transparent glass bottle sealed with screwed top in which a polyurethane foam (PUF, Tisch Environmental Inc) disk was put in to adsorb the emitted chlorinated decanes. The PUF disks were cleaned with hexane/dichloromethane $(1: 1, v / v)$ by an accelerated solvent extractor (Dionex ASE 350, Canada) before use.

During the hydroponic exposure, the water loss through volatile of water itself was determined by weighing the unplanted controls before and after exposure. It was found that the amount of water volatile was negligible. The water loss transpired from pumpkin seedlings of exposure group I was determined daily via weighing the reactors. Daily transpiration losses increased with plant growth. Accordingly, 8-12 mL/day of water were added into each reactor using a syringe to compensate the water loss. The amounts of water transpired from exposure group II were far lower than that of pumpkin seedlings in exposure group I because the seedlings were in airtight systems. Therefore, no water compensation was performed for exposure group II. The exposure was lasted for 10 days. 
Table 1

Information on commercial standards of individual chlorinated decane congeners.

\begin{tabular}{|c|c|c|c|c|c|}
\hline Congener cod/batch & Name & Formula & Structure & Purity (\%) & Concentration $(\mathrm{mg} / \mathrm{L})$ \\
\hline $\mathrm{CP}-3$ & 1,2,5,6,9-pentachlorodecane & $\mathrm{C}_{10} \mathrm{H}_{17} \mathrm{Cl}_{5}$ & & 99.1 & 10 \\
\hline $\mathrm{CP}-4$ & 1,2,5,6,9,10-hexachlorodecane & $\mathrm{C}_{10} \mathrm{H}_{16} \mathrm{Cl}_{6}$ & & 99.9 & 10 \\
\hline CP-6 & 1,2,4,5,9,10-hexachlorodecane & $\mathrm{C}_{10} \mathrm{H}_{16} \mathrm{Cl}_{6}$ & & 99.9 & 10 \\
\hline $\mathrm{CP}-7$ & 1,2,4,5,6,9,10-heptachlorodecane & $\mathrm{C}_{10} \mathrm{H}_{15} \mathrm{Cl}_{7}$ & & 99.9 & 10 \\
\hline $\mathrm{CP}-8$ & 1,2,5,5,6,9,10-heptachlorodecane & $\mathrm{C}_{10} \mathrm{H}_{15} \mathrm{Cl}_{7}$ & & $94.0^{\mathrm{a}}$ & 10 \\
\hline 9774 & 1,1,1,3,9,10-hexachlorodecane & $\mathrm{C}_{10} \mathrm{H}_{16} \mathrm{Cl}_{6}$ & & 96.3 & 100 \\
\hline
\end{tabular}

a The concentrations of decane standard solutions from Ehrenstorfer GmbH have been adjusted according to the purity of the compounds in the instruction. It means that $1 \mathrm{~mL}$ of the standard of 1,2,5,5,6,9,10-HepCD with concentration of $10 \mathrm{mg} / \mathrm{L}$ contained $10 \mu \mathrm{g}$ of HepCD instead of $9.4 \mu \mathrm{g}$ of HepCD.

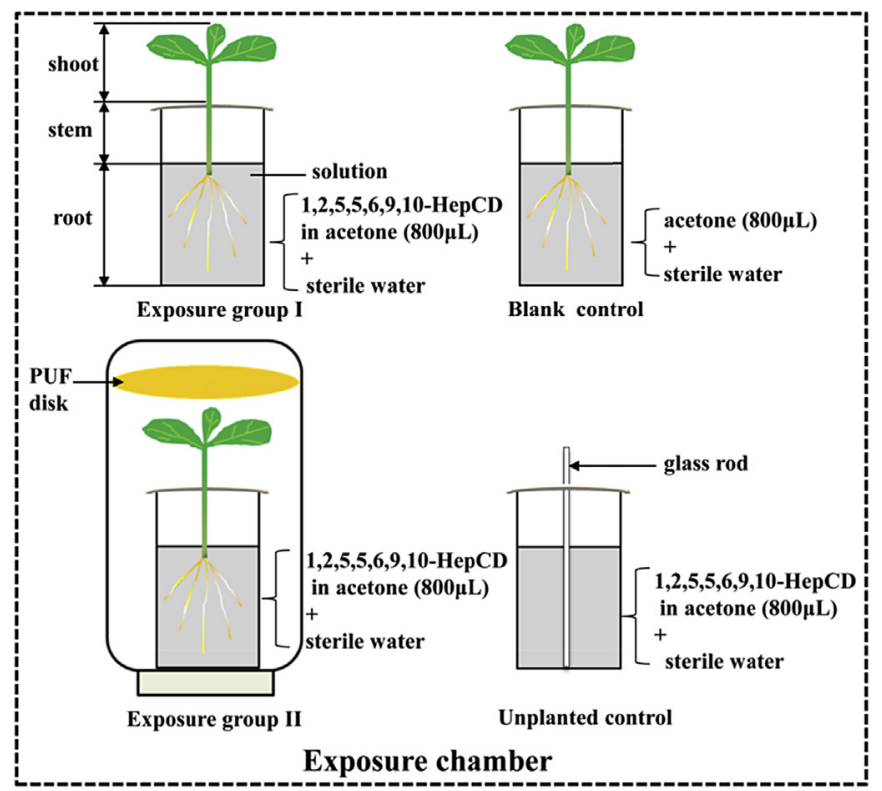

Fig. 1. Experimental design for exposure and control groups. All the reactors were wrapped with aluminum foil to prevent photodegradation.

\subsection{Sampling and sample preparation}

After 10 days exposure, seedlings were sampled and sectioned into roots, stems and shoots according to Fig. 1. Roots of plants were rinsed carefully by sterile deionized water. The rinse water was combined with the exposure solution for the determination of 1,2,5,5,6,9,10-HepCD. All the plant samples were gently dried with Kimwipes (Kimberly-Clark, Roswell, GA, USA), freeze-dried and stored at $-20^{\circ} \mathrm{C}$ before further treatment.

The extraction and clean up procedures for chlorinated decanes were similar to the method described by Zeng et al. (2011). The freeze-dried solid tissue samples were mixed with $10 \mathrm{~g}$ of anhydrous sodium sulfate, then spiked with $1 \mathrm{ng}$ of ${ }^{13} \mathrm{C}_{10}$-trans-chlordane and extracted with a mixture of $n$-hexane and dichloromethane $(1: 1, v / v)$ using an accelerated solvent extractor. The PUF disk, spiked with $1 \mathrm{ng}$ of ${ }^{13} \mathrm{C}_{10}$-trans-chlordane, was also extracted by ASE. The ASE parameters were as follows: temperature at $100{ }^{\circ} \mathrm{C}$, pressure of $1500 \mathrm{psi}$, thermal equilibration for $5 \mathrm{~min}$, static extraction for $7 \mathrm{~min}$, gaseous nitrogen purge for $100 \mathrm{~s}, 3$ runs. The lipid and some of the interferences were preliminary eliminated via adding $5 \mathrm{~g}$ of acid silica gel $(44 \%, w / w)$, shaking and then filtering through $5 \mathrm{~g}$ of anhydrous sodium sulfate. The anhydrous sodium sulfate was then rinsed by $30 \mathrm{~mL}$ of hexane. The combined extract was concentrated to $2 \mathrm{~mL}$ for further cleanup.

The water sample was transferred into a clean vial for liquidliquid extraction. The brown bottle for exposure was rinsed with dichloromethane $(2 \mathrm{~mL})$ for 3 times. The combined rinse solvent and another $9 \mathrm{~mL}$ of dichloromethane as well as $1 \mathrm{ng}$ surrogate standard, ${ }^{13} \mathrm{C}_{10}$-trans-chlordane, were added into the sample. Then the solution was extracted under violent shaking at $300 \mathrm{r} / \mathrm{min}$ for 30 min using an oscillator (Changzhou Guohua Electrical Appliance Co., LTD, China). The organic phase at the bottom was transferred with pasteur pipet into a clean flat-bottomed flask after phase separation. The water sample was re-extracted with $15 \mathrm{~mL}$ of dichloromethane twice. All the extracts were combined, dehydrated by $5 \mathrm{~g}$ of anhydrous sodium sulfate, and subsequently concentrated to about $2 \mathrm{~mL}$ for further cleanup.

Further cleanup was conducted by multilayer silica-florisil columns with $3 \mathrm{~g}$ of florisil, $2 \mathrm{~g}$ of activated silica gel, $5 \mathrm{~g}$ of acid silica gel $(30 \%, w / w), 4 \mathrm{~g}$ of anhydrous sodium sulfate from the bottom to the top. The columns were pre-cleaned by $50 \mathrm{~mL}$ of hexane. The sample was loaded and eluted with $35 \mathrm{~mL}$ of hexane to remove the impurities. Then $100 \mathrm{~mL}$ of dichloromethane/hexane $(1: 1, v / v)$ was employed to elute the analytes. The eluent was concentrated to about $2 \mathrm{~mL}$, dried by a gentle nitrogen stream and re-dissolved in $200 \mu \mathrm{L}$ of cyclohexane in a mini vial. In the end, $10 \mathrm{ng}$ of $\varepsilon-\mathrm{HCH}$ was added as injection standard and the mini vial was vortexed prior to instrumental analysis.

\subsection{Instrumental analysis}

An Agilent 7890A gas chromatograph (GC) coupled with a 7000B triple quadrupole mass spectrometer (MS) in single quad and ECNI mode (Agilent, Palo Alto, CA) was used for analysis of chlorinated decanes. All samples were injected by a 7683B series injector into a DB-5MS capillary column (30 $\mathrm{m} \times 0.25 \mathrm{~mm} \times 0.25 \mu \mathrm{m}$; Agilent, CA) with pulsed splitless mode. The temperature of injector and transfer line were $280{ }^{\circ} \mathrm{C}$. 
Helium was the carrier gas at a constant flow of $2.0 \mathrm{~mL} / \mathrm{min}$, and methane was the reagent gas at a constant flow rate of $0.40 \mathrm{~mL} /$ min. The column temperature program was isothermal at $100{ }^{\circ} \mathrm{C}$ (held for $1 \mathrm{~min}$ ), then increased at $30^{\circ} \mathrm{C} / \mathrm{min}$ to $160{ }^{\circ} \mathrm{C}$ and held for $5 \mathrm{~min}$. In the end, it was increased to $300^{\circ} \mathrm{C}$ at $30^{\circ} \mathrm{C} / \mathrm{min}$ and held for $12 \mathrm{~min}$. The ion source temperature was $200{ }^{\circ} \mathrm{C}$.

The qualitative analysis of chlorinated decanes was based on former work (Zeng et al., 2011). In brief, the two most abundant isotope ions of the $[\mathrm{M}-\mathrm{Cl}]^{-}$for chlorinated decanes were the qualitative and quantitative ions in selected ion monitoring (SIM) for congeners with different numbers of chlorine atoms (Table S1). Identification of the chlorinated decanes was further conducted by comparison of the retention time, signal shape and correct isotope ratio with those of standards. Quantitative analysis was performed by individual standards of chlorinated decanes according to the analytical protocol by Beaume et al. (2006). Namely, 1,2,5,6,9-PCD, $1,2,5,6,9,10-\mathrm{HexCD}$ and $1,2,5,5,6,9,10$-HepCD were used to quantify congeners of $\mathrm{C}_{10} \mathrm{H}_{17} \mathrm{Cl}_{5}, \mathrm{C}_{10} \mathrm{H}_{16} \mathrm{Cl}_{6}$, and $\mathrm{C}_{10} \mathrm{H}_{15} \mathrm{Cl}_{7}$, respectively.

\subsection{Quality assurance and quality control (QA/QC)}

To avoid potential contamination, all glassware were heated at $450{ }^{\circ} \mathrm{C}$ for $6 \mathrm{~h}$, and rinsed with dichloromethane three times before usage. One blank solvent was injected in each batch of 10 samples and no memory effect was found. The method detection limits (MDLs) for these individual chlorinated decane congeners were $0.19-0.41 \mathrm{ng} / \mathrm{mL}$ in water samples, and $4.5-52 \mathrm{ng} / \mathrm{g}$ dry weight in plant samples (Table S2). Spiking recoveries of 1,2,5,6,9-PCD, $1,2,5,6,9,10-\mathrm{HexCD}$ and $1,2,5,5,6,9,10-\mathrm{HepCD}$ were in the ranges of $74.8-101 \%, 87.6-117 \%$ and $88.1-111 \%$, respectively. The recoveries of surrogate standards in shoots, stems, roots and solutions were in the ranges of $67.1-87.4 \%, 70.3-81.1 \%, 84.8-108 \%$ and $74.0-104 \%$, respectively. Plant blanks in cultivation chamber were free from chlorinated decanes exposure. The levels of chlorinated decanes found in the plant blanks were shown in Table S3. All the reported results in this work were subtracted the plant blank and corrected by the surrogate recoveries.

The transformation ratio (TR) was the percentage of the transformed amount to the initial mass of the parent chemical. It was calculated based on the equimolar reaction between chlorinated decane and its dechlorination and chlorine rearrangement metabolites. The equation is shown as follow:

$\mathrm{TR}=\frac{\mathrm{m}_{\mathrm{B}} \cdot \mathrm{M}_{\mathrm{A}} \cdot 100 \%}{\mathrm{~m}_{\mathrm{A} 0} \cdot \mathrm{M}_{\mathrm{B}}}$

in which TR is the transformation ratio, $m_{B}$ is the mass of metabolites, $m_{A 0}$ is the initial mass of parent compound, $M_{A}$ and $M_{B}$ are the molecular weights of the parent compound and metabolites.

\section{Results and discussion}

\subsection{Uptake, translocation and phytovolatilization of parent compound}

The distribution of $1,2,5,5,6,9,10-\mathrm{HepCD}$ in different compartments of the reactors were analyzed to investigate the uptake and translocation of the parent compound in hydroponic exposure pumpkin seedlings. The results and distribution are shown in Table S4 and Fig. 2. Typical chromatograms of parent HepCD in different samples of exposure groups were shown in Fig. S1.

For exposure group I, only $31.6 \%$ of $1,2,5,5,6,9,10-\mathrm{HepCD}$ was found in the system. The largest portion of 1,2,5,5,6,9,10-HepCD within the pumpkins (about $29.3 \%$ of initial mass) was enriched in the roots. Less than $1 \%$ of initial mass of the parent chemical was

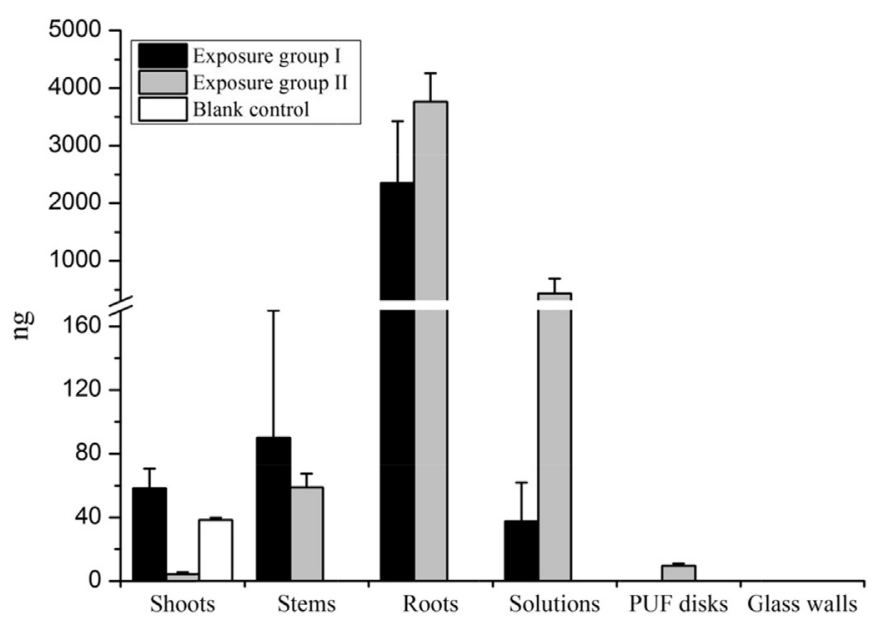

Fig. 2. The amounts of parent $1,2,5,5,6,9,10-\mathrm{HepCD}$ accumulated in different compartments of exposure systems and blank controls after pumpkins plants were hydroponically exposed for 10 days. Glass walls mean the walls of big containers of the exposure group II.

detected in shoots after 10-day hydroponic exposure. The mass distribution patterns of $1,2,5,5,6,9,10-\mathrm{HepCD}$ in reactors were solutions < shoots < stems < roots, indicating that exposure chemical was taken up by the roots and translocated from the roots to the shoots in pumpkin plants.

The mean total recovery of unplanted controls was $110 \pm 5 \%$, indicating that there was no loss of parent chemical during the exposure. The result suggested that volatilization and chemical transformation which might cause the loss of parent HepCD did not occur in the reactors without plants. Small amounts of parent HepCD $(38.2 \pm 1.6 \mathrm{ng})$ were detected in the shoots of the blank controls. The cross contamination in the shoots of blank controls could come from air phase as this group was kept in the same exposure chamber with HepCD exposure group I. Although the results of unplanted controls proved that parent HepCD did not directly volatilize from water, Collins et al. (2006) reported that organic pollutants were able to be emitted from the stomata of foliage via plant transpiration flux. Therefore, the 1,2,5,5,6,9,10HepCD captured by blank shoots might potentially origin from phytovolatile parent compound from pumpkins of exposure group I.

\subsection{Transformation of $1,2,5,5,6,9,10-$ HepCD mediated by pumpkins}

The total recovery of $1,2,5,5,6,9,10-\mathrm{HepCD}$ in unplanted control was much higher than that in exposure group I. The huge difference indicated that a large amount of exposure chemical was transformed and interfaced with the pumpkin plants. SCCPs are considered to be persistent and do not undergo direct photolysis under environmental conditions due to lack of appropriate chromophores absorbing UV light (>290 nm) (Feo et al., 2009). And no photolysis products of $1,2,4,5,6,9,10$-HepCD were found after 10 day light illumination in our preliminary experiment. In addition, no chemical transformation and volatilization occurred according to the unplanted controls. Therefore, the low recoveries of $1,2,5,5,6,9,10-$ HepCD in exposure group I suggested that pumpkin plants mediated the transformation of the tested compound.

Some halogenated organic compounds, such as PCBs and PBDEs, show dehalogenation and halogen rearrangement in plants (Liu et al., 2009; Wang et al., 2011a,b). The dechlorination of SCCPs had been reported under the role of nanoscale zero-valent iron (Zhang et al., 2012), indicating that SCCPs can be dechlorinated in 
suitable conditions. Thus, dechlorination and chlorine rearrangement products of $1,2,5,5,6,9,10-\mathrm{HepCD}$ in the whole pumpkin seedlings were investigated. Results showed that three congener groups, $\mathrm{C}_{10} \mathrm{H}_{17} \mathrm{Cl}_{5}, \mathrm{C}_{10} \mathrm{H}_{16} \mathrm{Cl}_{6}$, and other $\mathrm{C}_{10} \mathrm{H}_{15} \mathrm{Cl}_{7}$ (except $1,2,5,5,6,9,10$-HepCD), were identified as daughter chlorodecanes in pumpkin plants. Further dechlorination products with four chlorine atoms or less were not detectable because of their poor responses on ECNI-MS (Eljarrat and Barceló, 2006).

For exposure group $\mathrm{I}$, the dechlorination and chlorine rearrangement products, $\mathrm{C}_{10} \mathrm{H}_{17} \mathrm{Cl}_{5}, \mathrm{C}_{10} \mathrm{H}_{16} \mathrm{Cl}_{6}$, and other $\mathrm{C}_{10} \mathrm{H}_{15} \mathrm{Cl}_{7}$, were found in different compartments except the solutions. The mass distribution of the daughter chlorodecanes in whole plants was shown in Table S4 and Fig. 3. Shoots accumulated the majority of $\mathrm{C}_{10} \mathrm{H}_{16} \mathrm{Cl}_{6}$ and other $\mathrm{C}_{10} \mathrm{H}_{15} \mathrm{Cl}_{7}$, about 4-9 times higher than those in roots, and 21-35 times higher than those in stems. The congener profile of daughter chlorodecanes in shoots showed that the amounts of other $\mathrm{C}_{10} \mathrm{H}_{15} \mathrm{Cl}_{7}$ were higher than $\mathrm{C}_{10} \mathrm{H}_{16} \mathrm{Cl}_{6}$, while $\mathrm{C}_{10} \mathrm{H}_{17} \mathrm{Cl}_{5}$ was not detectable. The identification of those daughter chlorodecanes in plant tissues verified the transformation process of parent HepCD mediated by the pumpkins.

In blank controls, $\mathrm{C}_{10} \mathrm{H}_{17} \mathrm{Cl}_{5}, \mathrm{C}_{10} \mathrm{H}_{16} \mathrm{Cl}_{6}$ and other $\mathrm{C}_{10} \mathrm{H}_{15} \mathrm{Cl}_{7}$ were also found in different plant tissues (Table $\mathrm{S} 4$ and Fig. 3). The profile in the shoot samples showed that other $\mathrm{C}_{10} \mathrm{H}_{15} \mathrm{Cl}_{7}$ were higher than $\mathrm{C}_{10} \mathrm{H}_{16} \mathrm{Cl}_{6}$, but $\mathrm{C}_{10} \mathrm{H}_{17} \mathrm{Cl}_{5}$ was not detectable, which was similar to shoots of exposure group I. It suggested that shoots of blank controls and exposure group I went through the similar processes. Daughter chlorinated decanes were found in plant tissues within the reactor, indicating the translocation of chlorinated decanes from shoots to roots after pumpkins absorbed those daughter compounds from the air. The uptake of chlorodecanes by shoots and downward translocation resulted in the distribution of daughter chlorodecanes in plant tissues of blank controls being different from that of exposure group I. The amounts of $\mathrm{C}_{10} \mathrm{H}_{16} \mathrm{Cl}_{6}$ and other $\mathrm{C}_{10} \mathrm{H}_{15} \mathrm{Cl}_{7}$ in blank controls were highest in shoots, followed by stems, and then roots. In addition, those daughter chlorinated decanes might be further transformed after entering into blank pumpkins, which could also explain the different distribution patterns of daughter chlorodecanes in tissues of blank controls from those in exposure group I.

The impurities of $1,2,5,5,6,9,10$-HepCD standard were examined to ensure the authenticity of the experimental results. Lower chlorinated decanes of $\mathrm{C}_{10} \mathrm{H}_{17} \mathrm{Cl}_{5}, \mathrm{C}_{10} \mathrm{H}_{16} \mathrm{Cl}_{6}$ and other $\mathrm{C}_{10} \mathrm{H}_{15} \mathrm{Cl}_{7}$ were found with the amounts of $472 \mathrm{ng}, 708 \mathrm{ng}$ and $243 \mathrm{ng}$ in $800 \mu \mathrm{L}$ of $1,2,5,5,6,9,10-\mathrm{HepCD}$ standard (10 mg/L), respectively, which was consistent with those of unplanted controls (Table S4). It indicated that the other chlorinated decanes in unplanted controls came from the impurities of the parent HepCD standard. According to the quantitative results in Table S4, the amounts of $\sum \mathrm{C}_{10} \mathrm{H}_{17} \mathrm{Cl}_{5}$, $\sum \mathrm{C}_{10} \mathrm{H}_{16} \mathrm{Cl}_{6}$ and $\sum$ other $\mathrm{C}_{10} \mathrm{H}_{15} \mathrm{Cl}_{7}$ in exposure group I were higher than those in unplanted controls, in which the difference of $\sum$ other $\mathrm{C}_{10} \mathrm{H}_{15} \mathrm{Cl}_{7}$ was significant $(p<0.01)$. And the congener profiles of $\sum \mathrm{C}_{10} \mathrm{H}_{17} \mathrm{Cl}_{5}, \sum \mathrm{C}_{10} \mathrm{H}_{16} \mathrm{Cl}_{6}$ and $\sum$ other $\mathrm{C}_{10} \mathrm{H}_{15} \mathrm{Cl}_{7}$ in exposure group I were obviously different from those in unplanted controls (Fig. 4). Therefore, the transformation of $1,2,5,5,6,9,10$-HepCD mediated by the pumpkin seedlings definitely occurred in the exposure group I. Although impurities in parent compound standard might also be involved in the exposure experiments, their contribution could be negligible due to their initial low concentrations.

\subsection{Phytovolatilization and airborne transfer of chlorodecanes}

The parent and daughter compounds identified in the blank controls suggested the potential phytovolatilization and air transport of chlorodecanes. The mass balance results of exposure group I showed that only $68.3 \%$ of the administered parent HepCD was recovered (Table S5), showing the chlorodecanes could be phytovolatilized into the air phase in the open exposure system. Even when the parent HepCD transformed to daughter chlorodecanes were included, the total recoveries were still far less than $100 \%$. To further quantitatively study the phytovolatilization of parent HepCD and daughter cholordecanes, a sealed exposure system (exposure group II) was designed. In this system, the pumpkins were sealed in the big airtight containers, and PUF disks were placed in the headspace of the containers to seizure the parent and

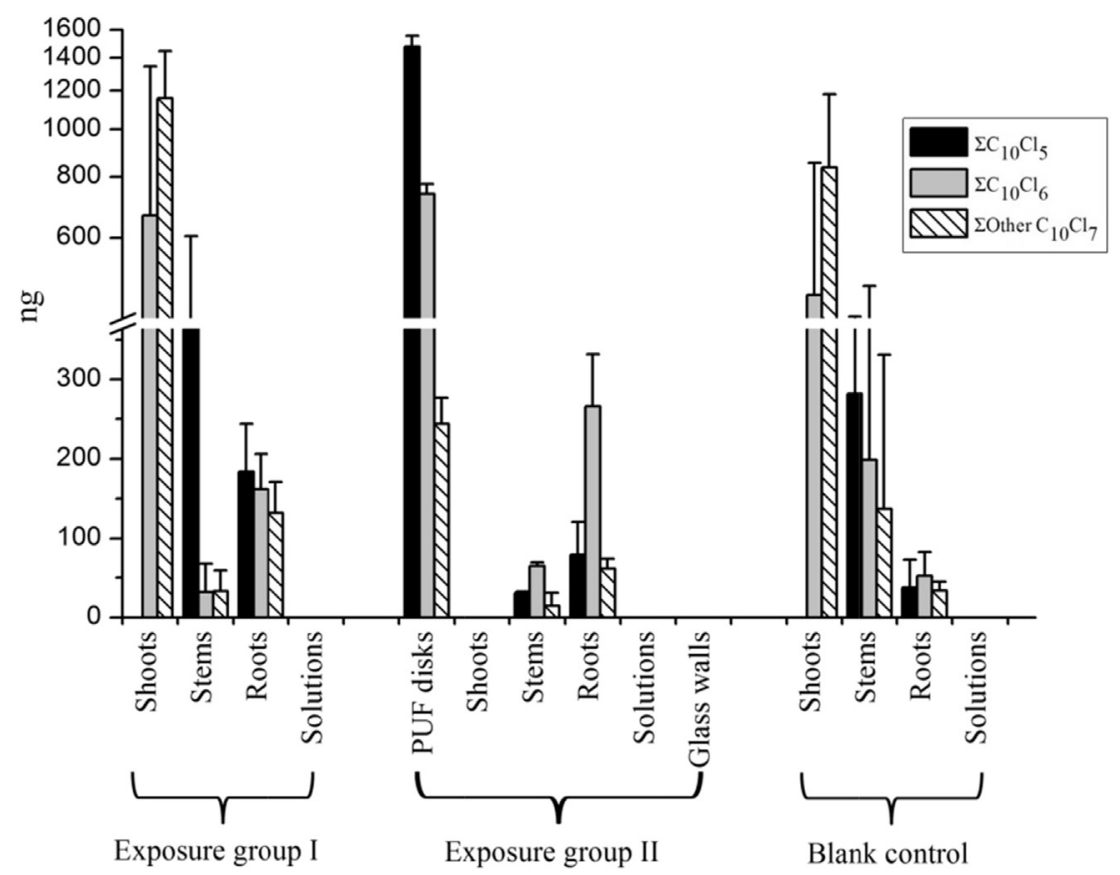

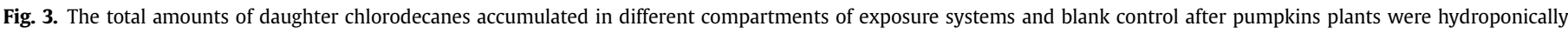
exposed for 10 days. Glass walls mean the walls of big containers of the exposure group II. 


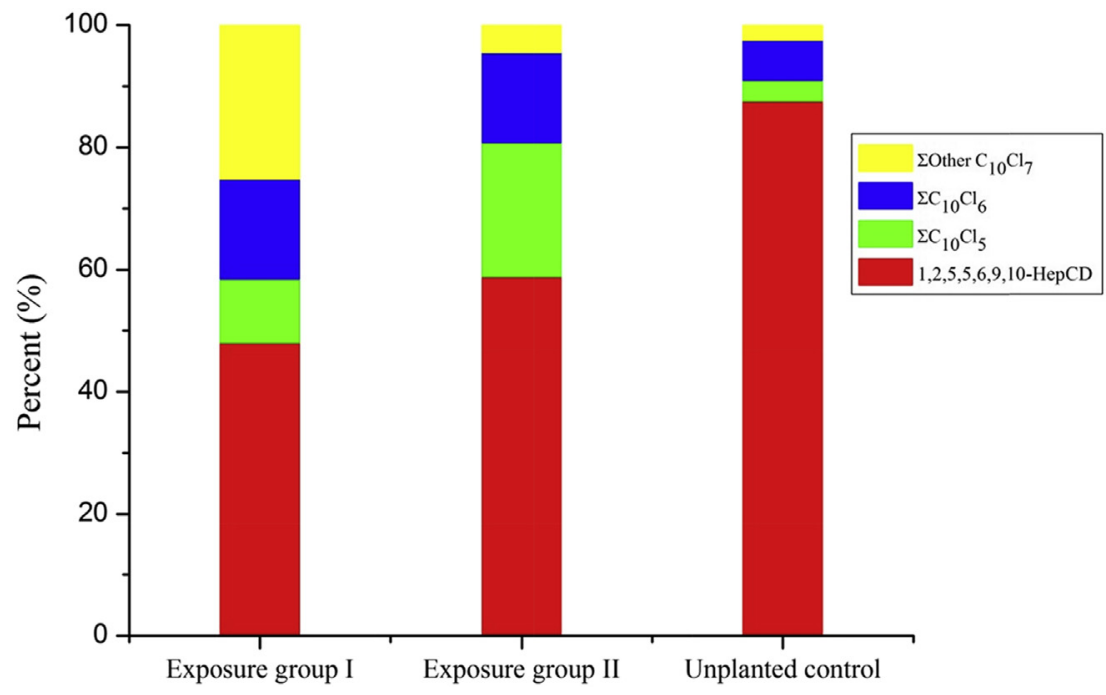

Fig. 4. The profile of $1,2,5,5,6,9,10$ - HepCD, other $\mathrm{C}_{10} \mathrm{H}_{15} \mathrm{Cl}_{7}, \mathrm{C}_{10} \mathrm{H}_{16} \mathrm{Cl}_{6}$ and $\mathrm{C}_{10} \mathrm{H}_{17} \mathrm{Cl}_{5}$ congeners in exposure groups and unplanted controls.

daughter compounds entering into the air phase. After the similar exposure process, all the samples including the plants, PUF disks and container glass wall were submitted for the analysis of both parent and daughter chlorodecanes.

The results showed that parent HepCD was detected in all the compartments of the exposure group II except the glass wall of the airtight container and daughter $\mathrm{C}_{10} \mathrm{H}_{17} \mathrm{Cl}_{5}, \mathrm{C}_{10} \mathrm{H}_{16} \mathrm{Cl}_{6}$ and $\mathrm{C}_{10} \mathrm{H}_{15} \mathrm{Cl}_{7}$ were detected in PUF disks, stems and roots (Table S4 and Fig. 3). When compared to the unplanted controls, the total amounts of daughter $\mathrm{C}_{10} \mathrm{H}_{17} \mathrm{Cl}_{5}, \mathrm{C}_{10} \mathrm{H}_{16} \mathrm{Cl}_{6}$ and other $\mathrm{C}_{10} \mathrm{H}_{15} \mathrm{Cl}_{7}$ in exposure group II were all significantly higher $\left(\mathrm{C}_{10} \mathrm{H}_{16} \mathrm{Cl}_{6}\right.$ and $\mathrm{C}_{10} \mathrm{H}_{7} \mathrm{Cl}_{5}$ $p<0.01$, other $\mathrm{C}_{10} \mathrm{H}_{15} \mathrm{Cl}_{7} p<0.05$ ), which further confirmed that the transformation of parent compound of HepCD occurred in exposure group II.

The contents of $\mathrm{C}_{10} \mathrm{H}_{16} \mathrm{Cl}_{6}$ and other $\mathrm{C}_{10} \mathrm{H}_{15} \mathrm{Cl}_{7}$ in pumpkins were higher in roots than those in stems, which was similar to the finding from exposure group I. The mass distribution patterns of 1,2,5,5,6,9,10-HepCD were shoots < PUF disks $<$ stems $<$ solutions $<$ roots. The mass of 1,2,5,5,6,9,10-HepCD associated with roots and left in solution were 1.6 and 11 times higher than that in exposure group I, respectively. Nevertheless, the masses of 1,2,5,5,6,9,10-HepCD enriched in stem and shoot, especially in shoots, was lower than those in exposure group I.

The differences of parent chemical accumulated in pumpkin tissues between exposure group I and II were evaluated by ANOVA method. The results showed significant differences between the contents of parent HepCD in roots $(p=0.05)$, shoots $(p<0.05)$ and solutions $(p<0.05)$ for the two exposure groups. Transpiration was generally used to evaluate the effects of stress on the vitality of plants. The data showed that the water loss through transpiration of exposure group I (8-12 mL/day) was higher than that of exposure group II ( $1.5 \mathrm{~mL} /$ day). This result indicated that the vitality of pumpkins in exposure group I (relatively open system in the exposure chamber) was higher than that of pumpkins in exposure group II (airtight systems). Thus, the uptake, translocation and phytovolatilization of parent HepCD in exposure group I were obviously stronger than those in exposure group II, resulting in the different distribution and accumulation profiles of parent HepCD in these two exposure groups.

In the PUF disks, only $0.1 \%$ of initial amount of $1,2,5,5,6,9,10-$ HepCD was detected, which was attributed to the phytovolatilization of parent HepCD from the pumpkin shoots. However, the PUF disks accumulated a large amount of daughter chlorodecanes, which were much higher than those in roots and stems. This finding indicated that PUF disk exhibited relatively higher capability for adsorbing the airborne chlorinated decanes than pumpkin shoots. Because of the block of airborne chlorinated decane translocation from shoots to roots by PUF disk, the small amounts of daughter cholorodecanes detected in the roots and stems were only from plant biotransformation origin, which further verified the biotransformation ability of the pumpkin tissues. Namely, the parent compound could be transformed in the plant tissues and the daughter chlorodecanes could be phytovolatilized into air phase.

It was very interesting to find that the daughter chlorodecanes were not detectable in shoots of exposure group II, which was different from the result of the exposure group I, although the parent HepCD could be detected in PUF disks and the shoots of both exposure group I and II. It could be inexplicable that no daughter chlorodecanes were detected in shoots of exposure group II if the biotransformation of the parent compound happened in plant shoots. The fact that the parent chlorodecane was transformed in the air after phytovolatilization could give another possibility. Plants were reported to emit various volatile organic compounds (VOCs) in which the reactive VOCs played an important role in the generation of radicals, such as the $\mathrm{OH}$ radicals in the atmosphere (Atkinson and Arey, 2003). The reaction possibilities between CPs and $\mathrm{OH}$ radicals in the atmosphere were predicted through DFT, QSAR, and Atkinson's OH-radical-reaction models (Atkinson, 1986; Li et al., 2014; Liu et al., 2015), suggesting the possible transformation of chlorodecanes induced by the existence of reactive VOCs or radicals. As discussed above, the similar profiles of daughter compounds in the shoots of blank controls and exposure group I further confirmed the possibility. It appeared that these two transformation processes, which were both related to pumpkins, might simultaneously exist for the parent compound of HepCD in the exposure system.

The congener profile of daughter chlorodecanes in PUF disks showed that the amount of $\mathrm{C}_{10} \mathrm{H}_{17} \mathrm{Cl}_{5}$ was the highest and followed by $\mathrm{C}_{10} \mathrm{H}_{16} \mathrm{Cl}_{6}$ and other $\mathrm{C}_{10} \mathrm{H}_{15} \mathrm{Cl}_{7}$, which were in contrast to the profiles in shoots of exposure group I. According to Collins et al. (2006), organic chemicals with high hydrophilism and vapor pressure are likely to be emitted from stomatal tissues of plants. SCCPs with a higher degree of chlorination have lower vapor pressure (Glüge et al., 2013). Therefore, $\mathrm{C}_{10} \mathrm{H}_{17} \mathrm{Cl}_{5}$ were much easier 
to be phytovolatilized from pumpkins than $\mathrm{C}_{10} \mathrm{H}_{16} \mathrm{Cl}_{6}$ and $\mathrm{C}_{10} \mathrm{H}_{15} \mathrm{Cl}_{7}$ after they were formed in the plants. While among the chlorodecanes formed in air phase, $\mathrm{C}_{10} \mathrm{H}_{17} \mathrm{Cl}_{5}$ also tend to persist in the air and was more difficult to be re-adsorbed and re-absorbed into the shoots due to its higher vapor pressure and volatility when compared to $\mathrm{C}_{10} \mathrm{H}_{16} \mathrm{Cl}_{6}$ and $\mathrm{C}_{10} \mathrm{H}_{15} \mathrm{Cl}_{7}$. That was why $\mathrm{C}_{10} \mathrm{H}_{17} \mathrm{Cl}_{5}$ was not found in shoots of exposure group I, but was highly accumulated in the PUF disks. The results of PUF disks verified that a large amount of $\mathrm{C}_{10} \mathrm{H}_{17} \mathrm{Cl}_{5}$ was produced and detained in the air phase.

\subsection{Behaviors of chlorodecanes in pumpkins}

According to the results of all those exposure groups and controls, besides the transformation and phytovolatilization processes, pumpkins in exposure group I have bidirectional translocation pathways, including uptake of chlorinated decanes from solution by roots and from air by shoots, translocation up from roots to shoots and down from shoots to roots. While for exposure group II, only absorption by roots existed and translocation up to shoots was predominant. For blank controls, there were only airborne chlorodecanes and the down to roots pathway was dominant. The various distributions of chlorinated decanes in the pumpkins in different groups were attributed to the comprehensive biological processes, and they were also affected by the physical and chemical properties of the parent and daughter chemicals.

\subsection{Transformation pathways}

The proposed transformation pathways of 1,2,5,5,6,9,10-HepCD related to young pumpkin plants are shown in Fig. 5, including the dechlorination and chlorine rearrangement processes. Chlorinated decanes with four or less chlorines which could not be detected by ECNI-MS (Eljarrat and Barceló, 2006) were likely produced in the exposure system.

In the sealed systems of exposure group II, all the bio-processes and potential losses were controlled and quantified, including loss through phytovolatilization which could not be quantified in exposure group I. Therefore, the fate of chlorinated decanes in the exposure group II was quantitatively studied (Table S5). The ratio of 53.3\% was detected for parent HepCD in exposure group II. The transformation ratios of parent HepCD to other $\mathrm{C}_{10} \mathrm{H}_{15} \mathrm{Cl}_{7}, \mathrm{C}_{10} \mathrm{H}_{16} \mathrm{Cl}_{6}$ and $\mathrm{C}_{10} \mathrm{H}_{17} \mathrm{Cl}_{5}$ accounted for $4.0,14.7$ and $24.2 \%$. The $3.8 \%$ non-

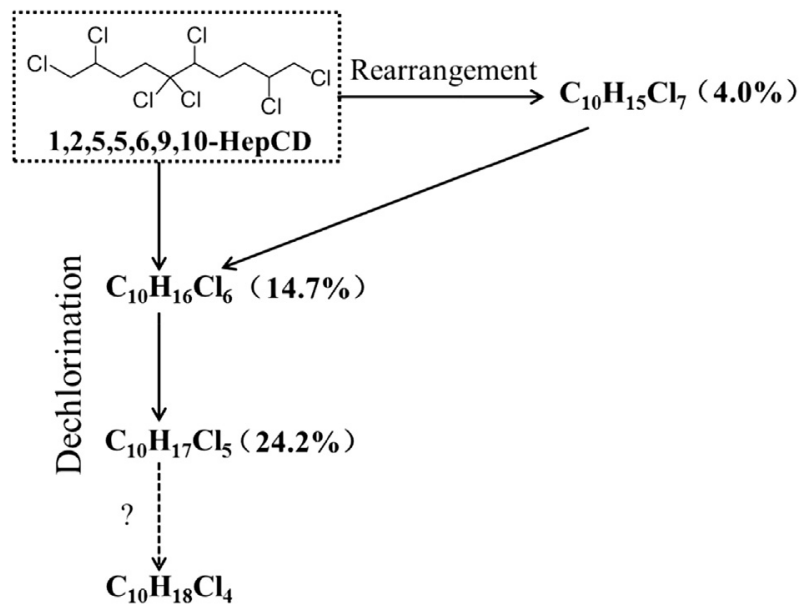

Fig. 5. The transformation pathways of $1,2,5,5,6,9,10-\mathrm{HepCD}$ mediated by pumpkin seedlings. Values in the brackets are the transformation ratios of parent compound to the daughter compounds. Dotted arrow with the question mark is the pathway which possibly occurs but is not able to be detected by GC/ECNI-LRMS. recovered $1,2,5,5,6,9,10-\mathrm{HepCD}$ indicated the possibilities of further dechlorination or production other transformation products that have not been accounted for. Dehalogenation, hydroxylation and even methoxylation are very common and important transformation pathways for organic pollutants in the environment. PCBs and PBDEs were able to be dehalogenated and hydroxylated by plants (Liu et al., 2009; Sun et al., 2013; Yu et al., 2013). Dechlorination was also observed for chlorinated decane, although the structures of 1,2,5,5,6,9,10-HepCD, PCBs and PBDEs were different. Thus, the chlorinated decanes in plants might also have metabolic pathways, such as methoxylation and hydroxylation in the similar way to some other POPs reported previously.

\section{Conclusion}

The uptake, translocation and transformation of 1,2,5,5,6,9,10HepCD in intact plants were explored by the in-lab hydroponic exposure experiments. It was found that pumpkins have bidirectional translocation pathways, including uptake of chlorinated decanes from solutions by roots and from air by shoots, translocation up from roots to shoots and down from shoots to roots. Chlorinated decanes can be phytovolatilized by the pumpkins. Two pumpkin plant mediated biotransformation pathways were found. The parent HepCD was found to be dechlorinated and chlorine rearranged in the plant tissues. Possible transformation occurring in the atmosphere was also proposed for the phytovolatilized HepCD interfaced with the reactive VOCs or radicals emitted by the pumpkins. To our knowledge, this is the first report on the transformation of 1,2,5,5,6,9,10-HepCD mediated by pumpkin plants. Though the hydroponic exposure system was different from the real soil-plant system in which HepCD tended to adsorb to soil and probably had less bioavailability, the results of this research provide important information on potential fate and biodegradation of persistent and toxic chlorinated decanes in the environment. The transformation of SCCPs with different chlorine patterns in the compound or possible radicals involved process are worthy of further studies regarding the explanation of the environmental fates for SCCPs.

\section{Acknowledgments}

This work was jointly supported by National Natural Science Foundation of China (No. 21337002), National Key Basic Research Program of China (2014CB441105), National Natural Science Foundation of China (No. 21621064) and Chinese Academy of Science (XDB14010400). JLS was supported by the Iowa Superfund Research Program (ISRP), National Institute of Environmental Health Science, Grant Number P42ES013661, and by the 1000Talents Program of the Chinese Academy of Sciences.

\section{Appendix A. Supplementary data}

Supplementary data related to this article can be found at http:// dx.doi.org/10.1016/j.envpol.2017.02.035.

\section{References}

Atkinson, R., 1986. Kinetics and mechanisms of the gas-phase reactions of the hydroxyl radical with organic-compounds under atmospheric conditions. Chem. Rev. 86, 69-201.

Atkinson, R., Arey, J., 2003. Gas-phase tropospheric chemistry of biogenic volatile organic compounds: a review. Atmos. Environ. 37, S197-S219.

Barber, J.L., Sweetman, A.J., Thomas, G.O., Braekevelt, E., Stern, G.A., Jones, K.C., 2005. Spatial and temporal variability in air concentrations of short-chain $\left(C_{10}\right.$ $\left.\mathrm{C}_{13}\right)$ and medium-chain $\left(\mathrm{C}_{14}-\mathrm{C}_{17}\right)$ chlorinated n-alkanes measured in the UK atmosphere. Environ. Sci. Technol. 39 (12), 4407-4415.

Bayen, S., Obbard, J.P., Thomas, G.O., 2006. Chlorinated paraffins: a review of 
analysis and environmental occurrence. Environ. Int. 32 (7), 915-929.

Beaume, F., Coelhan, M., Parlar, H., 2006. Determination of C10-chloroalkane residues in fish matrices by short column gas chromatography/electron capture negative ion low resolution mass spectrometry applying single pure and representative synthesised chlorodecanes as standards. Anal. Chim. Acta 565 (1), 89-96.

Burýśková, B., Bláha, L., Vršková, D., Šimková, K., Maršálek, B., 2006. Sublethal toxic effects and induction of glutathione S-transferase by short chain chlorinated paraffins (SCCPs) and C-12 alkane (dodecane) in Xenopus laevis frog embryos. Acta. Vet. Brno 75 (1), 115-122.

Chen, M.-Y., Luo, X.-J., Zhang, X.-L., He, M.-J., Chen, S.-J., Mai, B.-X., 2011. Chlorinated paraffins in sediments from the Pearl River Delta, South China: spatial and temporal distributions and implication for processes. Environ. Sci. Technol. 45 (23), 9936-9943.

Collins, C., Fryer, M., Grosso, A., 2006. Plant uptake of non ionic organic chemicals. Environ. Sci. Technol. 40 (1), 45-52.

Cooley, H.M., Fisk, A.T., Wiens, S.C., Tomy, G.T., Evans, R.E., Muir, D.C.G., 2001. Examination of the behavior and liver and thyroid histology of juvenile rainbow trout (Oncorhynchus mykiss) exposed to high dietary concentrations of $\mathrm{C}_{10^{-}}, \mathrm{C}_{11}$ $\mathrm{C}_{12}$ - and $\mathrm{C}_{14}$-polychlorinated n-alkanes. Aquat. Toxicol. 54 (1-2), 81-99.

Eljarrat, E., Barceló, D., 2006. Quantitative analysis of polychlorinated n-alkanes in environmental samples. TrAC Trends Anal. Chem. 25 (4), 421-434.

Feo, M.L., Eljarrat, E., Barceló, D., 2009. Occurrence, fate and analysis of polychlorinated n-alkanes in the environment. TrAC Trends Anal. Chem. 28 (6), $778-791$.

Fridén, U.E., McLachlan, M.S., Berger, U., 2011. Chlorinated paraffins in indoor air and dust: concentrations, congener patterns, and human exposure. Environ. Int. 37 (7), 1169-1174.

Gao, Y., Zhang, H.J., Su, F., Tian, Y.Z., Chen, J.P., 2012. Environmental occurrence and distribution of short chain chlorinated paraffins in sediments and soils from the Liaohe River Basin, P. R. China. Environ. Sci. Technol. 46 (7), 3771-3778.

Geng, N.B., Zhang, H.J., Zhang, B.Q., Wu, P., Wang, F.D., Yu, Z.K., Chen, J.P., 2015. Effects of short-chain chlorinated paraffins exposure on the viability and metabolism of human hepatoma HepG2 cells. Environ. Sci. Technol. 49 (5), 3076-3083.

Glüge, J., Bogdal, C., Scheringer, M., Buser, A.M., Hungerbühler, K., 2013. Calculation of physicochemical properties for short- and medium-chain chlorinated paraffins. J. Phys. Chem. Ref. Data 42, 023103.

Heath, E., Brown, W.A., Jensen, S.R., Bratty, M.P., 2006. Biodegradation of chlorinated alkanes and their commercial mixtures by Pseudomonas sp. strain 273. J. Ind. Microbiol. Biotechnol. 33, 197-207.

Hilger, B., Fromme, H., Volkel, W., Coelhan, M., 2011. Effects of chain length, chlorination degree, and structure on the octanol-water partition coefficients of polychlorinated n-alkanes. Environ. Sci. Technol. 45 (7), 2842-2849.

Houde, M., Muir, D.C.G., Tomy, G.T., Whittle, D.M., Teixeira, C., Moore, S., 2008. Bioaccumulation and trophic magnification of short- and medium-chain chlorinated paraffins in food webs from Lake Ontario and Lake Michigan. Environ. Sci. Technol. 42 (10), 3893-3899.

Huttig, J., Oehme, M., 2005. Presence of chlorinated paraffins in sediments from the North and Baltic Seas. Arch. Environ. Con. Tox. 49 (4), 449-456.

Iozza, S., Müeller, C.E., Schmid, P., Bogdal, C., Oehme, M., 2008. Historical profiles of chlorinated paraffins and polychlorinated biphenyls in a dated sediment core from Lake Thun (Switzerland). Environ. Sci. Technol. 42 (4), 1045-1050.

Li, C., Xie, H.B., Chen, J., Yang, X., Zhang, Y., Qiao, X., 2014. Predicting gaseous reaction rates of short chain chlorinated paraffins with.OH: overcoming the difficulty in experimental determination. Environ. Sci. Technol. 48, 13808-13816.

Li, Q.L., Li, J., Wang, Y., Xu, Y., Pan, X.H., Zhang, G., Luo, C.L., Kobara, Y., Nam, J.-J. Jones, K.C., 2012. Atmospheric short-chain chlorinated paraffins in China, Japan, and South Korea. Environ. Sci. Technol. 46 (21), 11948-11954.

Liu, J.Y., Hu, D.F., Jiang, G.B., Schnoor, J.L., 2009. In vivo biotransformation of 3,3',4,4' -tetrachlorobiphenyl by whole plants-poplars and switchgrass. Environ. Sci. Technol. 43 (19), 7503-7509.

Liu, J.Y., Schnoor, J.L., 2008. Uptake and translocation of lesser-chlorinated polychlorinated biphenyls (PCBs) in whole hybrid poplar plants after hydroponic exposure. Chemosphere 73 (10), 1608-1616.

Liu, R., Zhang, C., Kang, L., Sun, X., Zhao, Y., 2015. The OH-initiated chemical transformation of 1,2,4,6,8,10,11-heptachloroundecane in the atmosphere. RSC. Adv. 5, 37988-37994.

Lu, M., 2013. Degradation of short chain polychlorinated paraffins by a new isolate: tests in pure culture and sewage sludge. J. Chem. Technol. Biot. 88, 1273-1279.

Lunney, A.I., Zeeb, B.A., Reimer, K.J., 2004. Uptake of weathered DDT in vascula plants Potential for phytoremediation. Environ. Sci. Technol. 38 (22), 6147-6154.

Ma, X.D., Zhang, H.J., Wang, Z., Yao, Z.W., Chen, J.W., Chen, J.P., 2014
Bioaccumulation and trophic transfer of short chain chlorinated paraffins in a marine food web from Liaodong Bay, North China. Environ. Sci. Technol. 48 (10), 5964-5971.

Madeley, J.R., Birtley, R.D.N., 1980. Chlorinated paraffins and the environment. 2. Aquatic and avian toxicology. Environ. Sci. Technol. 14 (10), 1215-1221.

Marvin, C.H., Painter, S., Tomy, G.T., Stern, G.A., Braekevelt, E., Muir, D.C.G., 2003. Spatial and temporal trends in short-chain chlorinated paraffins in Lake Ontario sediments. Environ. Sci. Technol. 37 (20), 4561-4568.

Pellizzato, F., Ricci, M., Held, A., Emons, H., 2007. Analysis of short-chain chlorinated paraffins: a discussion paper. J. Environ. Monit. 9 (9), 924-930.

Rezek, J., Macek, T., Mackova, M., Triska, J., Ruzickova, K., 2008. Hydroxy-PCBs, methoxy-PCBs and hydroxy-methoxy-PCBs: metabolites of polychlorinated biphenyls formed in vitro by tobacco cells. Environ. Sci. Technol. 42 (15), 5746-5751.

Štejnarová, P., Coelhan, M., Kostrhounová, R., Parlar, H., Holoubek, I., 2005. Analysis of short chain chlorinated paraffins in sediment samples from the Czech Republic by short-column GC/ECNI-MS. Chemosphere 58 (3), 253-262.

Sun, J.T., Liu, J.Y., Yu, M., Wang, C., Sun, Y.Z., Zhang, A.Q., Wang, T., Lei, Z., Jiang, G.B., 2013. In vivo metabolism of 2,2',4,4'-tetrabromodiphenyl ether (BDE-47) in young whole pumpkin plant. Environ. Sci. Technol. 47 (8), 3701-3707.

Tomy, G.T., Fisk, A.T., Westmore, J.B., Muir, D.C., 1998. Environmental chemistry and toxicology of polychlorinated n-alkanes. Rev. Environ. Contam. Toxicol. 158, 53-128.

Tomy, G.T., Muir, D.C.G., Stern, G.A., Westmore, J.B., 2000. Levels of $C_{10}-C_{13}$ polychloro- $n$-alkanes in marine mammals from the Arctic and the St. Lawrence River estuary. Environ. Sci. Technol. 34 (9), 1615-1619.

Tomy, G.T., Stern, G.A., Lockhart, W.L., Muir, D.C.G., 1999. Occurrence of $C_{10}-C_{13}$ polychlorinated $n$-alkanes in Canadian midlatitude and arctic lake sediments. Environ. Sci. Technol. 33 (17), 2858-2863.

UNEP, 2015. Report of the Persistent Organic Pollutants Review Committee UNEP POPS/POPRC. 11/10. United Nations Environmental Programme Stockholm Convention on Persistent Organic Pollutants, Rome.

Wang, S., Zhang, S.Z., Huang, H.L., Lu, A.X., Ping, H., 2012a. Debrominated, hydroxylated and methoxylated metabolism in maize (Zea mays L.) exposed to lesser polybrominated diphenyl ethers (PBDEs). Chemosphere 89 (11), 1295-1301.

Wang, S., Zhang, S.Z., Huang, H.L., Zhao, M.M., Lv, J.T. 2011a. Uptake, translocation and metabolism of polybrominated diphenyl ethers (PBDEs) and polychlorinated biphenyls (PCBs) in maize (Zea mays L.). Chemosphere 85 (3), 379-385.

Wang, T., Han, S.L., Yuan, B., Zeng, L.X., Li, Y.M., Wang, Y.W., Jiang, G.B., 2012b. Summer-winter concentrations and gas-particle partitioning of short chain chlorinated paraffins in the atmosphere of an urban setting. Environ. Pollut. 171, $38-45$.

Wang, W., Delgado-Moreno, L., Ye, Q.F., Gan, J., 2011b. Improved measurements of partition coefficients for polybrominated diphenyl ethers. Environ. Sci. Technol. 45 (4), 1521-1527.

Wang, X.-T., Zhang, Y., Miao, Y., Ma, L.-L., Li, Y.-C., Chang, Y.-Y., Wu, M.-H., 2013. Short-chain chlorinated paraffins (SCCPs) in surface soil from a background area in China: occurrence, distribution, and congener profiles. Environ. Sci. Pollut. R. 20 (7), 4742-4749.

Yu, M., Liu, J.Y., Wang, T., Sun, J.T., Liu, R.Z., Jiang, G.B., 2013. Metabolites of 2,4,4'tribrominated diphenyl ether (BDE-28) in pumpkin after in vivo and in vitro exposure. Environ. Sci. Technol. 47 (23), 13494-13501.

Zencak, Z., Oehme, M., 2006. Recent developments in the analysis of chlorinated paraffins. TrAC Trends Anal. Chem. 25 (4), 310-317.

Zeng, L.X., Li, H.J., Wang, T., Gao, Y., Xiao, K., Du, Y.G., Wang, Y.W., Jiang, G.B., 2013. Behavior, fate, and mass loading of short chain chlorinated paraffins in an advanced municipal sewage treatment plant. Environ. Sci. Technol. 47 (2), $732-740$.

Zeng, L.X., Wang, T., Han, W.Y., Yuan, B., Liu, Q., Wang, Y.W., Jiang, G.B., 2011. Spatial and vertical distribution of short chain chlorinated paraffins in soils from wastewater irrigated farmlands. Environ. Sci. Technol. 45 (6), 2100-2106.

Zeng, L.X., Wang, T., Ruan, T., Liu, Q., Wang, Y.W., Jiang, G.B., 2012. Levels and distribution patterns of short chain chlorinated paraffins in sewage sludge of wastewater treatment plants in China. Environ. Pollut. 160, 88-94.

Zhai, G.S., Lehmler, H.-J., Schnoor, J.L., 2010a. Hydroxylated metabolites of 4-monochlorobiphenyl and its metabolic pathway in whole poplar plants. Environ. Sci. Technol. 44 (10), 3901-3907.

Zhai, G.S., Lehmler, H.-J., Schnoor, J.L., 2010b. Identification of hydroxylated metabolites of $3,3^{\prime}, 4,4^{\prime}$-tetrachlorobiphenyl and metabolic pathway in whole poplar plants. Chemosphere 81 (4), 523-528.

Zhang, Z.-Y., Lu, M., Zhang, Z.-Z., Xiao, M., Zhang, M., 2012. Dechlorination of short chain chlorinated paraffins by nanoscale zero-valent iron. J. Hazard. Mater 243, 105-111. 